Jakubowska, M. (2017). The role of cashless transactions in the process of limiting the scale of the shadow economy. Copernican Journal of Finance \& Accounting, 6(4), 23-37. http://dx.doi. org/10.12775/CJFA.2017.021

\author{
MARTA JAKUBOWSKA* \\ Nicolaus Copernicus University in Toruń
}

\title{
THE ROLE OF CASHLESS TRANSACTIONS IN THE PROCESS OF LIMITING THE SCALE OF THE SHADOW ECONOMY
}

Keywords: cashless transactions, shadow economy, payment cards.

J E L Classification: E42, G21, 033.

Abstract: This article presents the existing state of cashless transactions in Poland, taking into consideration the network of card acceptance among enterprises. Even though in recent years cashless transactions has been dynamically developing and using bank accounts and cashless payment instruments to carry out daily transactions is becoming more popular, the distance between the level of development of cashless transactions in Poland and that in other EU countries is still significant (NBP, 2013). According to the author, the possibility of two-way operations occurring between the cashless transactions and the shadow economy is both a very important and as of yet unverified research area. The literature describes the positive influence of the cashless transactions on the reduction of the shadow economy; the author, however, has attempted to determine whether the shadow economy can also influence the development of the cashless transactions. Therefore, the purpose of this article is to prove that limiting the use of cash money in the economy can indeed contribute to the reduction of the shadow economy. Two research methods are used in this article: literature study and statistical analysis. The study of literature concerning this subject has been carried out on the basis of domestic and foreign scientific journals and the quantified descrip-

Date of submission: March 13, 2018; date of acceptance: April 10, 2018.

* Contact information: marta.jakubowska.umk@gmail.com, Nicolaus Copernicus University in Toruń, Gagarina 13a, 87-100 Toruń, Poland, phone: +48 5661146 34; ORCID ID: https://orcid.org/0000-0001-9067-4524.

This work is supported by the Polish National Science Center Poland under Grant No. 2017/26/E/ HS4/00858. 
tion and the analysis of the shadow economy and cashless transactions have been based on extensive statistical data. According to a study, a tool that provides a possibility of the reduction of the shadow economy in the area of unregistered transactions shall be the launched Program Wsparcia Obrotu Bezgotówkowego.

\section{INTRODUCTION}

According to F. Schneider, the development of cashless transactions through a greater use of electronic payments creates the potential to reduce the functioning costs of the payment system and to limit the scale of transactions made in the shadow economy with the use of cash money (Schneider, 2011). However, cashless transactions still faces many difficulties It should be stressed that particularly strong dominance of cash payments can take place in transactions happening in physical points of sale (Polasik, 2013, pp. 79-102). Therefore, any actions, direct and indirect, performed by central bank, commercial banks and card manufacturers - currently under Program Wsparcia Obrotu Bezgotówkowego (the Programme for Support of Cashless transactions) - that promote the development of e-payment in economy are necessary (Borcuch, 2012, p. 68), what will be discussed later in the article.

\section{THE RESEARCH METHODOLOGY AND THE COURSE OF THE RESEARCH PROCESS}

Polish and foreign literature, statistical data from the European Central Bank and Narodowy Bank Polski and estimated from Institute for Market Economics have been used in this article. Based on the aforementioned sources, industryspecific analyses, data and analysed statistical tools, the growth of the shadow economy both in the EU and in Poland and the number of payment card transactions per capita have been presented. Moreover, the statistical analysis and literature study have been carried out. Furthermore, in this article, an attempt to verify the following hypothesis has been made (H1): In the countries that have highly advanced cashless transactions, the scale of the shadow economy phenomenon is smaller.

The article also uses the result of expert research of expected effects of Program Wsparcia Obrotu Bezgotówkowego implementation. The expert survey was implemented in 2017 by author on a group of 12 experts from Poland. 


\section{CASHLESS TRANSACTIONS}

Every use of cash on any level of clearing the accounts signifies cash accounting. It is historically considerably older payment method that cashless transactions and has been in existence since the invention of cash money. Cashless transactions, however, has only been around since the emergence of banks and bank accounts. Traditionally, the main types of cashless payments under the payment system are made via banks, between bank accounts of debtor and creditor. According to international statistics, such as the data from the European Central Bank presented on the figure (figure 1), cashless transactions includes three types of clearings:

- bank transfer order;

- payment order;

- clearance cheque;

- payment card.

The figure below shows the number of cashless transactions involving payment instruments per capita in Poland, on the background of the average value of this ratio in the European Union in the years 2001-2015. Even though in the recent years (figure 1), cashless transactions in our country has been dynamically developing, the number of cashless transactions per capita in Poland is still less than a half of European Union's average. It is a result of a fact that our country has been through political transformation and at the beginning of the 90 s the consumers were almost always only using cash. Therefore, it was necessary to build whole new modern payment system from the ground up and to change the existing consumers' habits (Schuh \& Stavins, 2013, pp. 246-272; Salmony, 2011, pp. 246-272). Actually, only one generation of Poles is able to use cashless payment instruments though all his life. In the year 2011, the number of transactions was still at a very low level (16 transactions per year per capita) compared to the average of the country of European Union of the day (134 transactions). Gradually the situation began improving, concerning both the number of bank accounts and payment card issued and the dynamic increase of the number of bank transfer and card transactions. 
Figure 1. The number of cashless transactions involving payment instruments per capita in the years 2001-2015

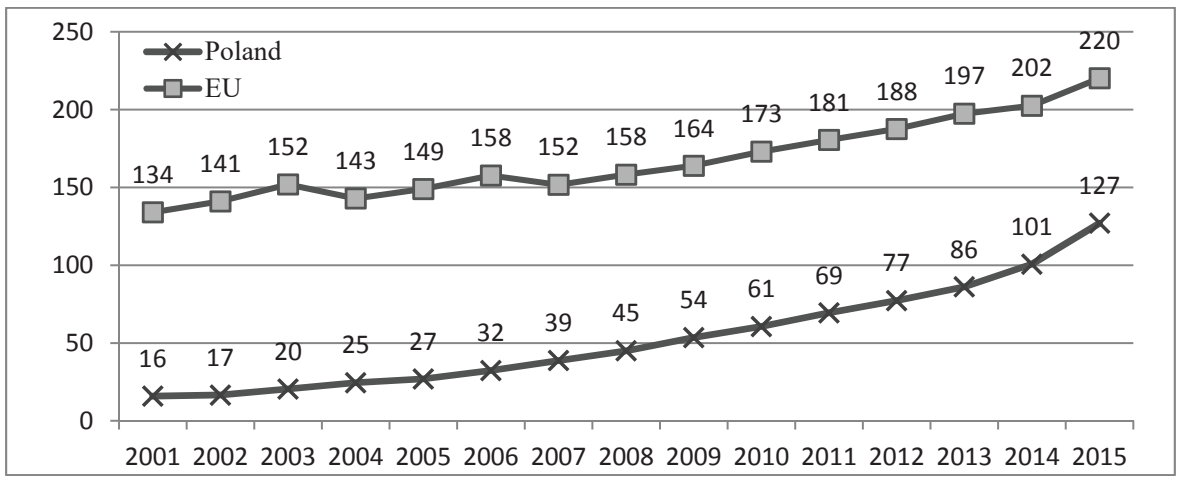

S o u r c e : developed personally based on: ECB, 2016.

\section{THE INFRASTRUCTURE OF PAYMENT CARDS ACCEPTANCE}

A payment system of a given country is: "a collection of mechanisms through which various forms of money are transferred between parties that fulfil they mutual obligations or act as mediators for a third party's payment services" (NBP, 2006, p. 5; own translation). However, according to the Payment Services Act, a specific payment system is: "a system of funds transfer based on formal and normalised regulations and shared rules on processing, billing or clearing payment transactions (...)" (Ustawa o usługach płatniczych 2011; own translation).

As a result, under the payment system infrastructure, the following elements can be distinguished (Narodowy Bank Polski, Związek Banków Polskich \& Koalicja na Rzecz Obrotu Bezgotówkowego i Mikropłatności, 2009; own translation):

- intermediary institutions in making clearing (providing payment services),

- payment systems,

- authorisation and clearing systems that process transactions executed by electronic payment instruments,

- service points that accept transactions made via payment cards,

- $\mathrm{ATMs}^{1}$.

${ }^{1}$ Cash transactions are not analyzed in this article. 
Payment cards are issued under the payment system and create a market of payment cards, which is a so-called two-way market (Rochet \& Tirole, 2003, pp. 990-1029; Rochet \& Tirole, 2008, pp. 1333-1347). Within this market we can distinguish its following participants (Maciejewski, 2013, pp. 58-78):

- Merchants - retailers accepting payment for goods or services via payment cards,

- Consumers - customers who pay by card for goods or services at servicing points,

- Card issuers - subjects (most often banks) that issue payment cards to consumers,

- Clearing agents - manage clearing between card issuers and merchants. Clearing agents are banks or non-banking subjects that make deals with merchants on charging the fees for card usage.

- Card association - institutions that bring together payment card issuers within their own payment system. They provide their members with a logo (trademark) and a payment system. The basic source of association's income are fees from card transactions (interchange fees) collected by clearing agents.

EFT-POS terminal is a device used for operations with cashless payments that is installed in sales and service points and is essential for contacting bank server (via certificate authority) in the moment of paying for goods or services with a payment card (Świecka, 2011, p. 29).

Figure 2. The number of merchants and EFT-POS terminal in Poland (in thousands)

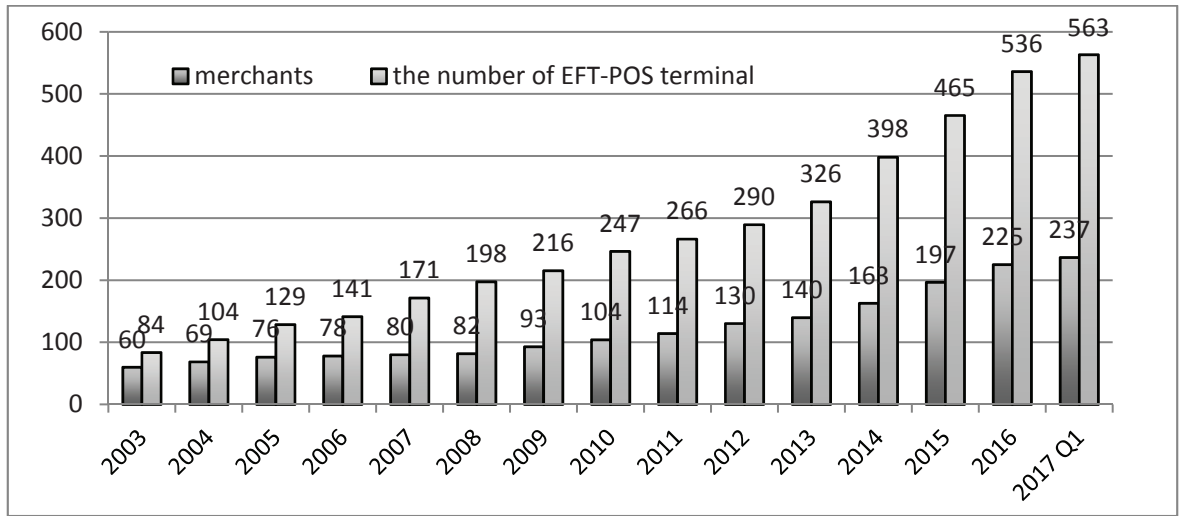

S o u r c e : developed personally based on: NBP, 2017. 
From 2003 until the beginning of 2017 (figure 2), the number of payment cards merchants increased almost four times - from 60 thousand to 237 thousand. A significant leap in payment cards acceptance took place at the turn of 2014 and 2015, due to the reduction of interchange payment in Poland (NBP, 2015; Jonker, 2011). Therefore, the number of terminals in Poland was, relatively, dynamically increasing in the aforementioned period (figure 3) - from 84 thousand to 563 thousand in the first quarter of 2017. It proves that Poles have more opportunities for cashless payments). Moreover, as the result of the actions taken under the name of cashless transactions and the appointment of Program Wsparcia Obrotu Bezgotówkowego, the number of EFT-POS terminals should significantly increase in the coming years, by another 600 thousand devices (Polityka Insight, 2017, p. 9). This programme is further discussed in the later part of the article.

Figure 3. The reach of payment cards acceptability in Poland in relative terms in 2012

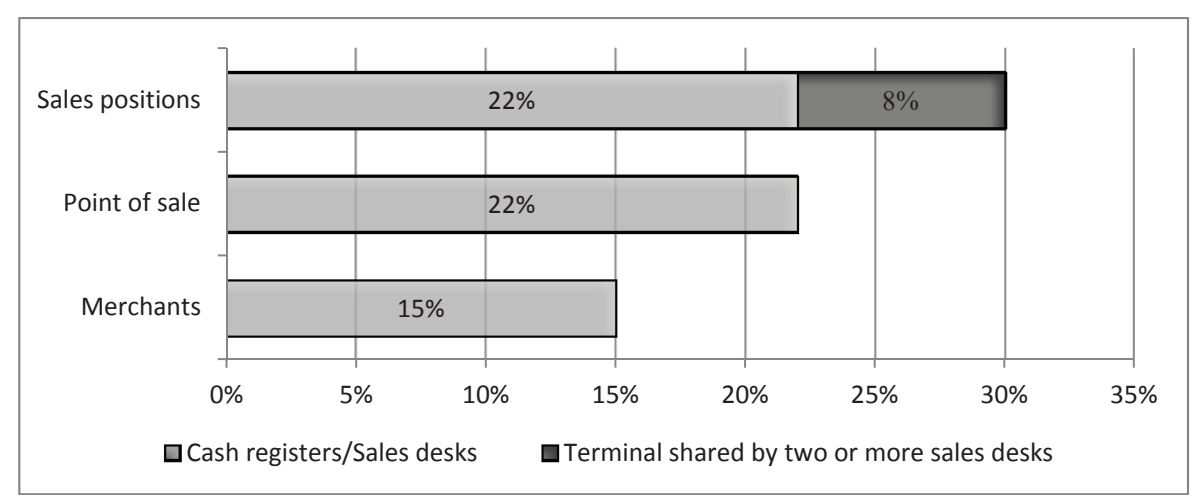

S o u r c e : developed personally based on: Polasik, 2015.

M. Polasik's research estimates the number of active subjects providing goods and services to individual customers in Poland in December 2012 to 899 thousand. This number is viewed as a reference point for the conclusions and statistics presented in the article. On the basis of the aforementioned research, it can be stated that the general reach of payment cards acceptability in Poland in 2012 (figure 3) was about 15\% (merchants), so it was very limited. Taking into consideration another indicator, concerned with the number of all points of sale where customers were serviced, the reach of payment cards acceptabil- 
ity was estimated to be around 29\%. This results explicitly indicate that trade and services sector in 2012, in most cases, did not accept payment cards and that the dominant payment instrument was cash money (Polasik, 2015, p. 42).

Assuming, that number of active subjects providing goods and services has not changed since 2012 (899 thousand entities) and referring it to the number of merchants - basing on the source from NBP in 2017 (figure 2), i.e. 237 thousand. - we can estimate the acceptance range of cards by merchants at approximately $1 / 4$ of all entities. Thus, the payment card market in Poland has changed positively over the years 2013-2017, but still, around 3/4 of entities do not accept payment cards.

\section{PAYMENT INSTRUMENTS USED IN POLAND IN PHYSICAL POINTS OF SALE}

From this article's point of view, the most important area of retail payments are payments in physical points of sale, which in the year 2011 accounted for $76 \%$ of the number of all transactions made by consumers (Polasik, 2013, pp. 79-102). It results from the fact that physical sales channels (shops, service points, workshops, etc.) are the most susceptible to the shadow economy problem, as transactions carried out there can be anonymous. However, in the case of e-commerce or invoices, there is some kind of transaction registration, the so-called "electronic trace" (e.g. by issuing an invoice or placing an order online, via an e-retailer or auction platform). Which is why in this article the author is concentrating on the infrastructure of cashless payments in physical points of sale, as a key element for the subject matter - fighting with the shadow economy. In reality, so far only payment cards are being used on a larger scale in physical payment, what is analysed below.

\section{THE VALUE AND NUMBER OF PAYMENT CARD TRANSACTIONS}

Over the years 1999-2016 (figure 4) both the value and the number of payment card transactions were gradually increasing. As for the value of payment card transactions, the most significant change can be seen in 2015. Compared to the previous year, that value has increased by some 75 billion PLN and the number of transaction by over 0.5 billion. Having analysed the number of transactions, it can be stated that the biggest increase the number of payment card transactions happened at the turn of 2014 and 2015, which can be related to the inter- 
change reduction for bank operations, in order to motivate Poles to use payment cards more often (NBP, 2015).

Figure 4. The value and number of payment card transactions in Poland in the years 1999-2016

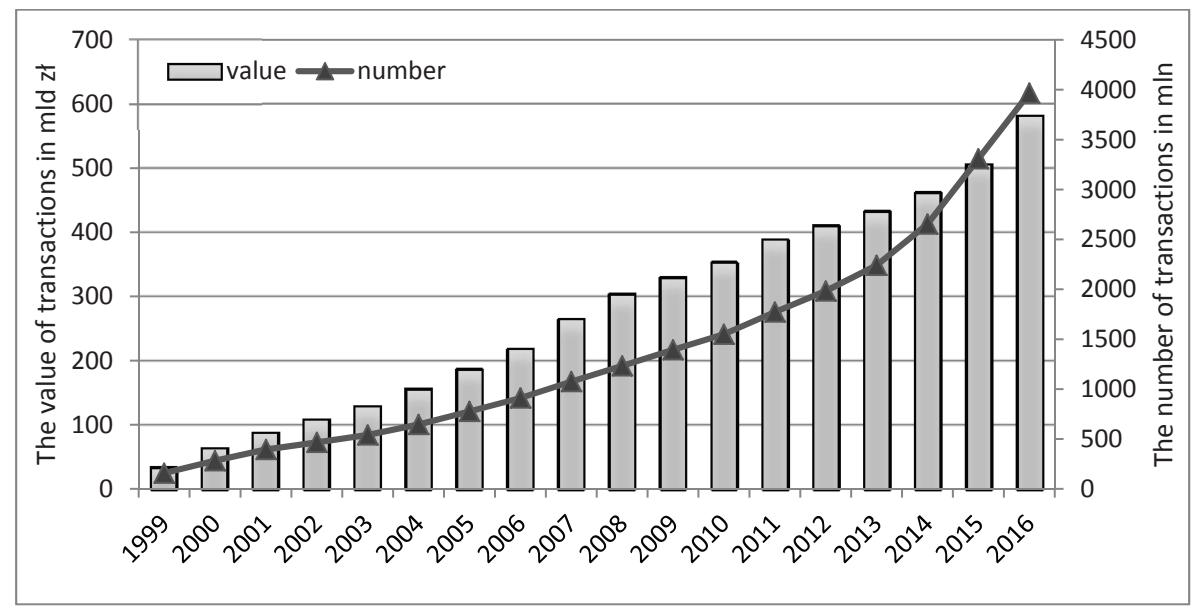

S o u r c e : developed personally based on: NBP, 2017.

Considering the fact that contactless payments are becoming more popular, the tendency illustrated in the figure above (figure 4) should be maintained in the coming years (Borcuch, 2011). While analysing another table (figure 5), one must remember about the dominant role of payment card in cashless transactions. In the first quarter of $2017,83 \%$ of payment card transactions are cashless transactions. The remaining part are cash transactions, i.e. cash withdrawal from ATMs, and also, on a smaller scale, cash back operations in payment terminals. Cash transactions are becoming less present in all transactions in general (figure 5). 
Figure 5. The number of cashless transactions in the number of all card transactions in Poland in the years 2004-2017

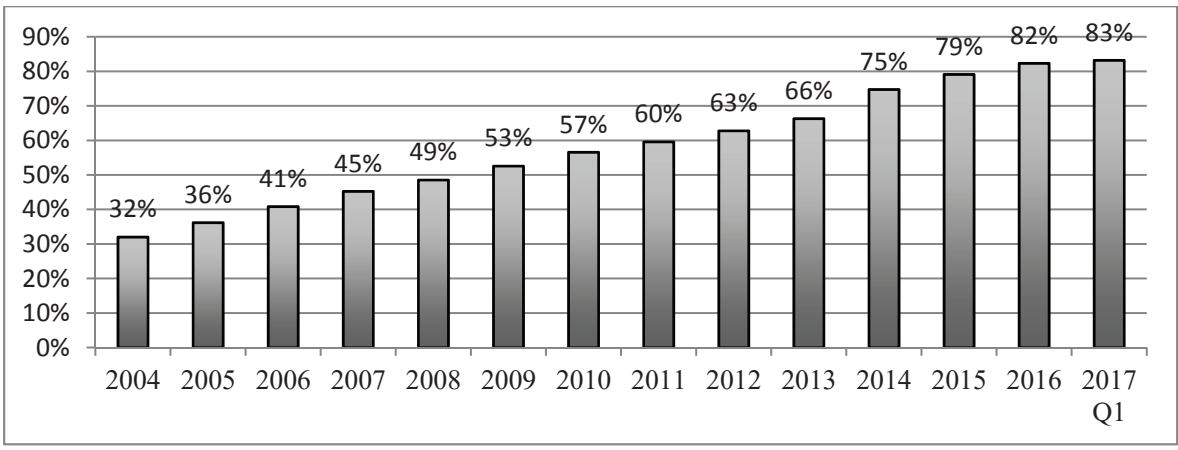

S o u r c e : developed personally based on: NBP, 2017.

\section{THE INFLUENCE OF CASHLESS PAYMENTS ON THE SIZE OF THE SHADOW ECONOMY IN CHOSEN EUROPEAN UNION COUNTRIES}

Prof. Friedrich Schneider's literature overview (Schneider, 2013, pp. 1-24) has pointed to a negative correlation between the shadow economy and the number of cashless transactions, particularly those involving payment cards (Schneider, 2011). Furthermore, the research on the situation in Greece has shown that in the time of a financial crisis, when the access to the cash was hampered, which in turn popularised the use of payment cards, increase VAT tax revenue was observed (Hondroyiannis \& Papaoikonomou, 2017, pp. 17-20). The author has conducted her own research on the relationship between cashless transactions and the size of the shadow economy.

In many countries, cashless transactions is dynamically developing, thus offering perspective to create cashless society. The visit of payment market where all invoices and debts are paid using cashless payment instruments is slowly becoming more real. The main barrier stopping the creation of such society is society's preference to remain anonymous in transactions. This preference collides with public institutions' operations for using cashless transactions, which aims to gain larger control over economic operators and natural persons. It is driven by the necessity to limit the shadow economy, but it can also be met with resistance from the society (Polasik \& Maciejewski, 2009, pp. 501-506). Over the last few years in Poland, changing approach to cashless 
transactions could be observed, which is illustrated by the figures in the previous subchapters on the number of cards issued, the number of merchants and terminals and ATMs. Consumers' preferences are becoming more favourable for the usage of payment cards and the number of transactions made with them is increasing (NBP, 2016, p. 26). Not without significance, in this case, is also the fact that in the recent years a radical increase of the number of payment terminals could be observed, which also influenced the development of cashless transactions in Poland. It all suggests the following correlation - the bigger the cashless transactions, the smaller the shadow economy.

Figure 6. A compilation of the shadow economy (\% PKB) and the number of cashless transactions made with payment cards per capita in the EU countries in 2015

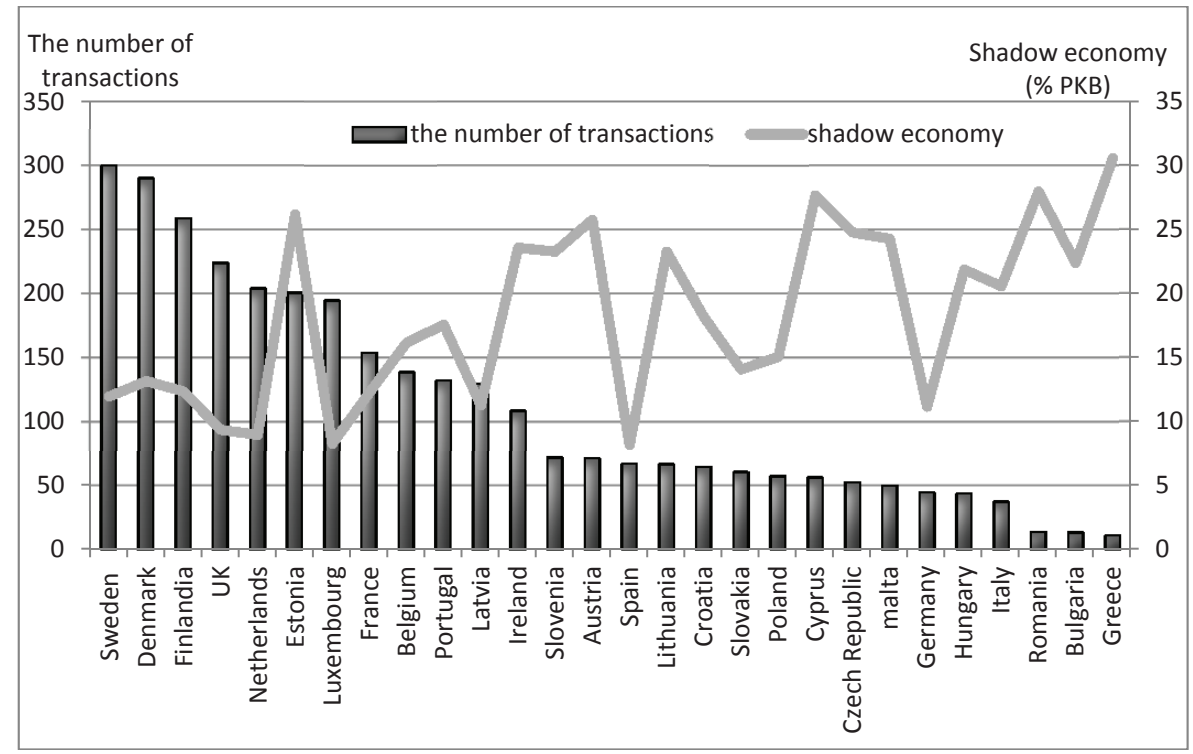

S o u r c e : developed personally based on: Fundowicz, Łapiński, Peterlik \& Wyżnikiewicz, 2016; ECB, 2016.

In the figure (figure 6) above once can notice the aforementioned relationship concerning the number of cashless transactions made with payment cards 
per capita and the level of the shadow economy in $2015^{2}$. In the European countries, where the number of transactions per capita is the largest, the shadow economy assumes relatively lower percentage of the Gross National Product (GNP). The Person's correlation coefficient, which was calculated by the author on the basis of the data above (figure 6), is -0.57 .

The above correlation dependence of the empirical data was verified by the t-student significance test for the Pearson's correlation coefficient, which was used to verify the following hypotheses:

$\mathrm{H}_{0}$ : no correlation between the number of cashless transactions made with payment cards per capita in the EU and the size of the shadow economy,

$\mathrm{H}_{1}$ : there is a correlation between the number of cashless transactions made with payment cards per capita in the EU and the size of the shadow economy.

$|\mathrm{t}|=3.57$,

$\mathrm{t}_{\alpha, \mathrm{s}}=0.49$, where $\alpha=0.05, \mathrm{~s}=26$.

Since $|t| \geq t_{\alpha, s^{\prime}}$ we reject the null hypothesis about the irrelevance of Pearson's correlation coefficient, at the significance level of 0.05 . We can assume that the correlation coefficient is statistically significant.

The above studies indicate that there is a dependency between the number of cashless transactions made with payment cards per capita in the EU. It is a negative correlation of a relatively large force, which confirms the hypothesis accepted in the article that: In the countries that have highly advanced cashless transactions, the scale of the shadow economy phenomenon is smaller.

\section{CURRENT ACTIONS FOR THE DEVELOPMENT OF CASHLESS TRANSACTIONS in Poland - Program WsParcia Obrotu BezgotówKowego}

According to the data from the Ministry of Development, the level of cashless transactions is one of the important indicators of the country's economic growth and access to digital payment is of a great importance for the entrepreneurs. Which is why, on June 12, 2017, an appropriate agreement has been signed between The Polish Bank Association (ZBP), the Ministry of Finance and Development and the biggest payment card providers. Under this agreement,

${ }^{2}$ Upon completion of this paper, the European Central Bank's statistical data on cashless transactions made with payment cards per capita for the year 2016 were not available. 
the Foundation "Polska Bezgotówkowa" (Cashless Poland) has been appointed, in accordance with the government project "Od papierowej do cyfrowej Polski" (From paper to digital Poland). The Foundation "Polska Bezgotówkowa" shall lead the programme of the development of payment card acceptability in Poland. The programme's goal is to support entrepreneurs in launching EFTPOS terminals and to cover transaction fees, particularly in small and medium companies (Money, 2017). Initially, the number of EFT-POS terminals is to be increased by some 600 thousand devices in three years. Program Wsparcia Obrotu Bezgotówkowego is being created as the initiative of financial market's subjects participating in domestic card payment market, i.e. banks - card providers, clearing agents, leaders in the Polish payment organisations market and also ZBP and the Minister of Development and Finance. The Programme's goal is to popularise cashless payments and make them as available as cash payments through supporting the development of acceptance network in Poland (Związek Banków Polskich, 2017). The implementation of the Programme would be a revolutionary change in Poland.

The following (figure 7) are the results of expert research conducted by the author in 2017 on a group of 12 experts: presidents of leading companies dealing with electronic payment settlement (VISA, Mastercard), representatives of commercial banks (PeKaO SA), employees of leading on the polish acquirers? (First Data, Polskie e-Płatności) and clearing house (KIR). The representative of the Ministry of Finance also took the floor.

Figure 7. Assessment of potential effects of the Program Wsparcia Obrotu Bezgotówkowego

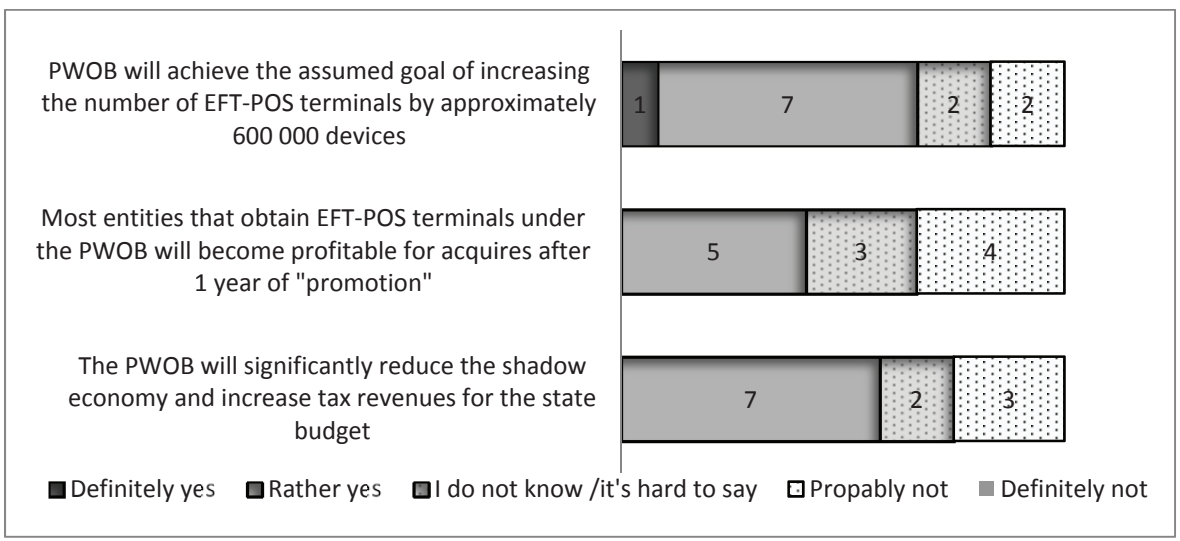

S o u r c e: own research, $2017 ; n=12$. 
In the case of a question regarding the potential effects of PWOB (figure 7), the vast majority of Experts predicted the success of the Cashless Payment Support Program, which assumes an increase in the number of terminals by approximately 600,000 devices. However, taking into account the profitability of the supported companies after one year from the implementation of the Programme, the Experts' opinions differ. Some Experts have significant concerns about the financial viability of the Programme for acquirers. Moreover the expert study confirms that the Program will probably limit scale of shadow economy (figure 7).

The expert study conducted by the author of this article confirms that the Program may contribute to limiting the scale of the shadow economy in the scope of unregistered transactions.

\section{CONCLUSION}

Taking into consideration the research above, increasing cashless transactions should significantly level out the shadow economy. Unfortunately, it is not happening mainly because only legal transactions are replaced by card transactions, the same is not with illegal ones. We are dealing with two-way relationship. On the one hand, cashless transactions can reduce the shadow economy, on the other hand, the shadow economy can block this accounting. In the environment with the large congregation of the shadow economy, no one wants to register payments. Therefore, a solution that would force payments registration seems necessary, particularly in industries subjected to the shadow economy. This solution could also contribute to the increase of accounting and the reduction of the scale of unregistered transactions. A promising solution, which is well-functioning in other countries is online fiscal system. The question whether such a system would work in Poland still remains open.

Currently, due to the fact that there is abundance of payment cards in Poland and the market is dynamically developing, the main direction of increase of many circulations through the development of cashless transactions is through the development of card acceptance network. Thus, a tool that provides a possibility of the reduction of the shadow economy in the area of unregistered transactions shall be the launched Program Wsparcia Obrotu Bezgotówkowego. Due to the fact that this Programme is the first attempt in the world to introduce full acceptance of cards in the economy, the results are very popular among international experts. Undoubtedly, it is an area for future studies. 


\section{REFERENCES}

Borcuch, A. (2011). Bankowość elektroniczna w Polsce. (Electronic Banking in Poland.) Warszawa: CeDeWu.

Borcuch, A. (2012). Wpływ rynku płatności elektronicznych na ograniczanie szarej strefy. (The Impact of the Electronic Payment Market on Reducing the Shadow Economy.) Finanse, (Finance.) 1(5), 68-80.

ECB (2016). Statistical Data Warehouse, http://sdw.ecb.europa.eu/reports. do?node=1000005713 (accessed: 11.07.2017).

Fundowicz, J., Łapiński K., Peterlik M., \& Wyżnikiewicz, B. (2016). Szara strefa w polskiej gospodarce w 2016 roku. (The Gray Zone in Polish Economy in 2016.) Warszawa: IBnGR.

Hondroyiannis, G., \& Papaoikonomou, D. (2017). The Effect of Card Payments on Vat Revenue: New Evidence from Greece. Economics Letters, 157, 17-20. http://dx.doi. org/10.1016/j.econlet.2017.05.009.

Jonker, N. (2011). Card Acceptance and Surcharging: The Role of Costs and Competition. Review of Network Economics, 10(2). http://dx.doi.org/10.2202/1446-9022.1249.

Maciejewski, K. (2013). Uczestnicy obrotu bezgotówkowego na rynku polskim. (Participants of Cashless Transactions on the Polish Market.) In H. Żukowska, M. Żukowski (Eds.). Obrót bezgotówkowy w Polsce. (Cashless Transactions in Poland.) Lublin: Wydawnictwo KUL.

Money (2017). MR: PWOB przyspieszy wzrost liczby terminali, (PWOB Will Accelerate the Increase in the Number of Terminals.) http://www.money.pl/gielda/wiadomosci/artykul/mr-program-wsparcia-obrotu-bezgotowkowego,115,0,2332531.html (accessed: 11.07.2017).

NBP (2006). Strategia rozwoju systemu płatniczego i obrotu bezgotówkowego w Polsce. (Strategy for the Development of the Payment System and Cashless Transactions in Poland.) Warszawa: Departament Systemu Płatniczego.

NBP (2013). Diagnoza stanu rozwoju obrotu bezgotówkowego w Polsce. (Diagnosis of the Development of Cashless Transactions in Poland.) Warszawa: Departament Systemu Płatniczego.

NBP (2015). Analiza skutków obniżenia opłaty interchange w Polsce. (Analysis of the Effects of the Reduction of the Interchange Fee in Poland.) Warszawa: Departament Systemu Płatniczego.

NBP (2016). Wybrane wyniki badania Polaków nt. korzystania z usług bankowych i płatności 2016. (Selected Results of the Survey of Poles on the Use of Banking Services and Payments 2016.) Warszawa: Departament Systemu Płatniczego.

NBP (2017). System płatniczy, (Payment System.) http://www.nbp.pl/home.aspx?f=/ systemplatniczy/dane_i_analizy.html (accessed: 11.07.2017).

Narodowy Bank Polski, Związek Banków Polskich, \& Koalicja na Rzecz Obrotu Bezgotówkowego i Mikropłatności(2009).Strategia rozwoju obrotu bezgotówkowego w Polsce na lata 2009-2013, (Strategy for the Development of Cashless Transactions in Poland for the Years 2009-2013.) http://www.nbp.pl/SystemPlatniczy/ Obrot_bezgotowkowy/rob_projekt.pdf (accessed: 18.04.2018). 
Polasik, M. (2013). Innowacje płatnicze stosowane w fizycznych punktach sprzedaży - szansa dla obrotu bezgotówkowego w Polsce. (Payment Innovations in Physical Points of Sale - An Opportunity for Cashless Transactions in Poland.) In H. Żukowska, M. Żukowski (Eds.). Obrót bezgotówkowy w Polsce. (Cashless Transactions in Poland.) Lublin: Wydawnictwo KUL.

Polasik, M. (2015). Stan i potencjał rozwoju sieci akceptacji kart płatniczych w Polsce. (Status and Potential for the Development of the Payment Card Acceptance Network in Poland.) Acta Universitatis Nicolai Copernici. Ekonomia, 46(1), 23-58. http:// dx.doi.org/10.12775/AUNC_ECON.2015.002.

Polasik, M., \& Maciejewski, K. (2009). Bariery rozwoju społeczeństwa bezgotówkowego w Polsce. (Barriers to the Development of Cashless Society in Poland.) In S. Partycki (Ed.). E-gospodarka, E-społeczeństwo w Europie Środkowej i Wschodniej. Tom 2. (E-economy, E-society in Central and Eastern Europe. Volume 2.) Lublin: Wydawnictwo KUL.

Polityka Insight (2017). Raport finansowy. (Financial Report.) Warszawa.

Rochet, J.-C., \& Tirole, J. (2003). Platform Competition in Two-Sided Markets. Journal of the European Economic Association, 1(4), 990-1029. http://dx.doi.org/ $10.1162 / 154247603322493212$.

Rochet, J.-C., \& Tirole, J. (2008). Tying in Two-Sided Markets and the Honor All Cards Rule. International Journal of Industrial Organization, 26(6), 1333-1347. http:// dx.doi.org/10.1016/j.ijindorg.2008.01.002.

Salmony, M. (2011). Why Is Use of Cash Persisting? Critical Success Factors for Overcoming. Journal of Payments Strategy \& Systems, 5(3), 246-272.

Schneider, F. (2011). The Shadow Economy in Europe, 2011: Using Electronic Payment Systems to Combat the Shadow Economy. Linz: A.T. Kearney.

Schneider, F. (2013). The Shadow Economy in Europe, 2013. Linz: A.T. Kearney.

Schuh, S., \& Stavins, J. (2013). How Consumers Pay: Adoption and Use of Payments. Accounting and Finance Research, 2(2), 1-21. http://dx.doi.org/10.5430/afr.v2n2p1.

Świecka, B. (2011). Bankowość elektroniczna. (Electronic Banking.) Warszawa: CeDeWu.

Ustawa o usługach płatniczych z dnia 19 sierpnia 2011r. (The Law of Payment Services, August 19, 2011).

Związek Banków Polskich (2017). ZBP na rzecz Programu Wsparcia Obrotu Bezgotówkowego, (ZBP for the PWOB.) http://zbp.pl/wydarzenia/archiwum/wydarzenia/2017/ czerwiec/zbp-na-rzecz-programu-wsparcia-obrotu-bezgotowkowego (accessed: 12.07.2017). 